\title{
COLACIUM MINIMUM (EUGLENOPHYTA), A NEW EPIPHYTIC SPECIES FOR ASIA
}

\author{
Konrad Wolowski, Kritsana Duanguan ${ }^{1} \&$ Yuwadee Peerapornpisal
}

\begin{abstract}
Colacium minimum Fott \& Komárek, known so far from a few localities in Central Europe (Czech Republic), is reported here for the first time from Asia (Thailand). This epiphytic species was found growing on eight taxa of loricated euglenoids. The process of surface colonization of Trachelomonas Ehrenb. and Strombomonas Deflandre taxa by $C$. minimum in natural populations is briefly discussed and originally documented using LM and SEM.
\end{abstract}

Key words: Colacium minimum, Eurasia, lorica, Strombomonas, Trachelomonas, Thailand

Konrad Wolowski, Department of Phycology W. Szafer Institute of Botany, Polish Academy of Sciences, Lubicz 46, 31-512 Kraków, Poland; e-mail: k.wolowski@botany.pl

Kritsana Duangjan, Science and Technology Research Institute, Chiang Mai University, Chiang Mai, 50200, Thailand; e-mail: kritsana.du@gmail.com

Yuwadee Peerapornpisal, Department of Biology, Faculty of Science, Chiang Mai University, Chiang Mai, 50200, Thailand; e-mail: yuwadee.p@cmu.ac.th

\section{INTRODUCTION}

Epibionts usually are simply defined as organisms that spend most of their life cycle attached to the surface of other organisms. The phenomenon of epibionts is well known worldwide. It often occurs among algae. The most frequently reported algal epiphytes include diatoms, chlorococcal green algae, golden algae and yellow green algae. Classic examples are found in data from Chudyba (1965), who recognized epiphytic algal communities consisting of 226 taxa (1 Schizomycetes, 19 Cyanobacteriae, 1 Chrysophyceae, 176 Bacillariophyceae, 1 Xanthophyceae, 27 Chlorophyta and 1 Rhodophyta) which were attached to Cladophora glomerata (L.) Kützing.

The mutual effects between epiphytes and hosts have been studied for a long time. Many observations indicate that the plant substrate affects the algal communities of epiphytes both physically and chemically. According to Whitton (1970), one probable reason for the large number of epiphytes on threads of Cladophora glomerata

\footnotetext{
1 Corresponding author
}

or mosses (Kawecka 1980) is that the roughened surface of the substrate is easily colonized by organisms. Smooth surfaces make cell adhesion to the surface difficult. Epiphytes are also observed among euglenoid flagellates, but only in the genus Colacium Ehrenb.

The genus Colacium is widespread, with 9 (Starmach 1983) to 25 (Silva 2007) species described, which are typically epibionts on freshwater arthropods. The most interesting observations on Colacium were reported by Rosowski and Kugrens (1973). Using their own observations of natural collections and from studies in clonal culture, they showed that in nature Colacium was found only on zooplankton and never attached to filamentous algae in the laboratory, such as Cladophora Kützing, Stigeoclonium Kützing, Enteromorpha Link or other available littoral substrates. In the laboratory they observed only Colacium vesiculosum Ehrenb. - nine attached to Mougeotia sp. and Volvox tertius Art. Mey. That work and later ones (Rosowski \& Willey 1977; Willey \& Giancarlo 1986) do not, however, give data on the 

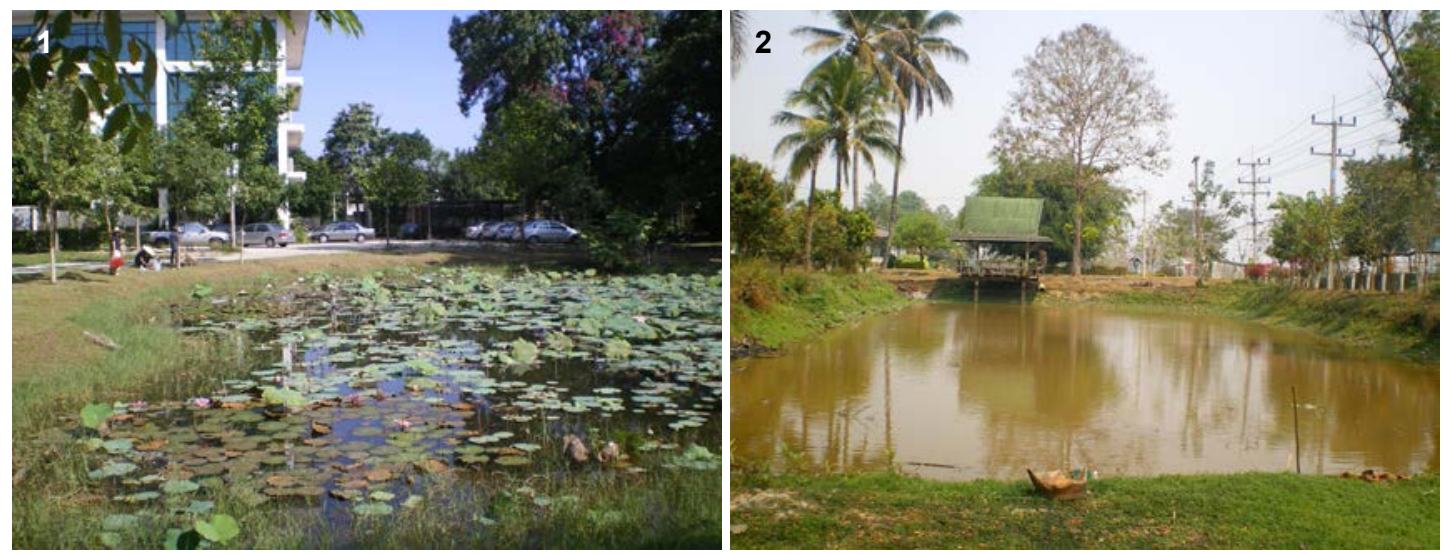

Figs 1 \& 2. 1 - Garden pond near the Faculty of Agriculture at Chiang Mai University (AG). 2 - Garden pond at Tobacco Center Pa Ko Dam (BY1).

occurrence of Colacium on the surface of loricated taxa of euglenoids. Colacium attached to loricated euglenoids has been reported so far by Skvortzov (1957), Fott and Komárek (1960), Kaštovský et al. (2009) and Juráň (2010).

Here we report the occurrence of an algal species on the loricae surface of Strombomonas and Trachelomonas, and discuss this phenomenon.

\section{MATERIALS AND METHODS}

Samples were taken from April 2009 to March 2010 in Chiang Mai and Chiang Rai Provinces, Thailand. The highest diversity of euglenoids was noted at 13 sampling sites. Colacium sp. was reported at only two of them: the first was a shallow garden pond with Lotus spp. and transparent water near the Faculty of Agriculture at Chiang Mai University, (AG) (Fig. 1), and the second one was a shallow garden pond with mud at the bottom and turbid water at Tobacco Center Pa Ko Dam (BY1) (Fig. 2).

Samples were collected using a plankton net $(10 \mu \mathrm{m}$ pore size) into a plastic flask ( $c a 100 \mathrm{ml})$ and divided into two parts: one preserved with Lugol's solution and studied by SEM, and the other transported fresh to the laboratory and studied by LM. All descriptions are from morphological observations of living specimens, using a Nikon ELIPSE 600 light microscope. The Strombomonas, Trachelomonas and Colacium species were also studied using a Hitachi S-4700 SEM.

The physicochemical properties of the water, such as $\mathrm{pH}$, conductivity and nutrients (nitrate, ammonium and soluble reactive phosphorus, SRP; Table 1), were analyzed by standard methods (Greenberg et al. 2005). Taxonomical data were checked by reference to HuberPestalozzi (1955), Fott and Komárek (1960), Wołowski (1998, 2011), Wołowski and Hindák (2005), Duangjan et al. (2012) and Duangjan \& Wołowski (2014).

Table 1. Range of values of physicochemical parameters of water in garden ponds near the Faculty of Agriculture at Chiang Mai University (AG) and Tobacco Center Pa Ko Dam (BY1).

\begin{tabular}{l|c|c}
\hline Parameter & AG & BY1 \\
\hline${\mathrm{P}-\mathrm{PO}_{4}[\mathrm{mg} / \mathrm{L}]}_{\mathrm{N}-\mathrm{NO}_{3}[\mathrm{mg} / \mathrm{L}]}$ & $0.02-0.11$ & $0.03-0.17$ \\
$\mathrm{~N}-\mathrm{NH}_{4}[\mathrm{mg} / \mathrm{L}]$ & $0.27-0.43$ & $0.07-1.00$ \\
$\mathrm{DO}[\mathrm{mg} / \mathrm{L}]$ & $0.02-0.04$ & $0.09-0.61$ \\
$\mathrm{BOD}[\mathrm{mg} / \mathrm{L}]$ & $3.47-3.73$ & $3.1-9.9$ \\
Alkalinity $\left[\mathrm{mg} / \mathrm{L} \mathrm{CaCO}_{3}\right]$ & $4.40-5.00$ & $2.7-12.7$ \\
Conductivity $\left[\mu \mathrm{S} / \mathrm{cm}^{2}\right]$ & $41-43$ & $28-71$ \\
$\mathrm{pH}$ & $130-148$ & $93-194$ \\
Temp. of water $\left[{ }^{\circ} \mathrm{C}\right]$ & $22.6-27.7$ & $25.0-31.2$ \\
Temp. of air $\left[{ }^{\circ} \mathrm{C}\right]$ & $27.0-29.8$ & $27.5 .-33.7$ \\
\hline
\end{tabular}

\section{RESULTS AND DISCUSSION}

The physical and chemical parameters of the two investigated ponds (BY1, AG) did not differ greatly. Ammonium nitrogen and nitrate nitrogen levels were higher in BY1 than in AG. BOD was highest in BY1. The physicochemical paramaters of the water in AG were stable (Table 1).

Among the 13 sampling sites showing the highest euglenoid diversity, epiphytes attached to 
Table 2. Taxa similar to Colacium minimum Fott \& Komárek reported by various authors.

\begin{tabular}{|c|c|c|c|c|c|}
\hline Taxa & Dimension & Chloroplast & Stigma & Paramylon & Ecology \\
\hline $\begin{array}{l}\text { Sykidion droebakense Wille } \\
\text { (Wille 1901) }\end{array}$ & $6-9 \mu \mathrm{m}$ in diameter & $\begin{array}{l}\text { one, with } \\
\text { pyrenoid }\end{array}$ & - & - & $\begin{array}{l}\text { surface of filamentous } \\
\text { algae }\end{array}$ \\
\hline $\begin{array}{l}\text { Characiopsis epiphytica Bour- } \\
\text { relly \& Georges } \\
\text { (Bourrelly \& Georges } 1953 \text { ) }\end{array}$ & $\begin{array}{l}6-10 \mu \mathrm{m} \text { in } \\
\text { diameter }\end{array}$ & 1 to 5 , discoid & - & - & $\begin{array}{l}\text { surface of loricated } \\
\text { euglenoids }\end{array}$ \\
\hline $\begin{array}{l}\text { Colacium trachelomonoides } \\
\text { Skvortzov } \\
\text { (Skvortzov 1957) }\end{array}$ & - & 2 lateral & - & - & $\begin{array}{l}\text { surface of } \\
\text { Trachelomonas sp. }\end{array}$ \\
\hline $\begin{array}{l}\text { Colacium minimum Fott \& } \\
\text { Komárek } \\
\text { (Fott \& Komárek 1960) }\end{array}$ & 3-7 $\mu \mathrm{m}$ in diameter & $\begin{array}{l}\text { 3-4 parietal } \\
\text { without } \\
\text { pyrenoids }\end{array}$ & small, dark & several small & $\begin{array}{l}\text { epiphyte on loricated } \\
\text { euglenoids and } \\
\text { planktonic diatoms }\end{array}$ \\
\hline $\begin{array}{l}\text { Colacium minimum } \\
\text { (this paper) }\end{array}$ & $\begin{array}{l}2.5-4.6 \mu \mathrm{m} \text { long, } \\
3.70-4.11 \mu \mathrm{m} \text { wide }\end{array}$ & $\begin{array}{l}3-4 \text { parietal } \\
\text { without } \\
\text { pyrenoids }\end{array}$ & small, red & several tiny & $\begin{array}{l}\text { surface of loricated } \\
\text { euglenoids }\end{array}$ \\
\hline
\end{tabular}

the surface of euglenoid species were observed in only two garden ponds: $A G$ in October and December, and BY1 from March to July and in October. A total of 253 euglenoid taxa were identified at the two sites. The most species-rich genera were Trachelomonas Ehrenb. (99 taxa), Phacus Dujardin (45), Strombomonas Deflandre (30), Euglena Ehrenb. (27) and Lepocinclis Perty (24). A few taxa of Petalomonas (6), Euglenaria (5), Peranema Dujardin (4), Anisonema Dujardin (3), Cryptoglena Ehrenb. (2), Monomorphina Mereschkowsky emend. Kosmala \& Zakryś (2), Notosolenus Stokes (2), and single taxa of Discoplastis Triemer, Entosiphon Stein, Heteronema Dujardin, Rhabdomonas Fresenius were occasionally observed. The percentages of all

AG
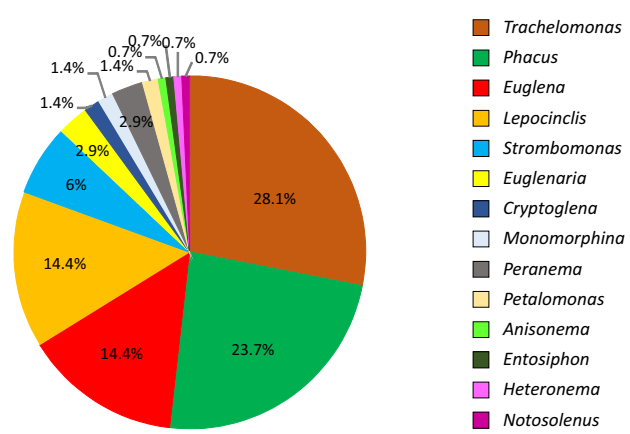

Fig. 3. Percentage of euglenoids occurring at AG site. euglenoids identified at the two sites are given in Figures 3 and 4.

Colacium minimum attached only to members of two loricated genera among the total 16 euglenoid genera occurring in the garden ponds. Taxonomical study showed that two species of Strombomonas [S. australica (Playfair) Deflandre (Fig. 5), S. fluviatilis (Lemmerm.) Deflandre (Fig. 6)] and six taxa of Trachelomonas [T. akressiensis Da \& Couté (Fig. 7), T. cervicula var. heterocollis Svirenko (Figs $11 \& 12$ ), T. intermedia f. papillifera Popova (Fig. 13), T. mirabilis var. helvetica Huber-Pestalozzi (Figs 10 \& 14), T. peerapornpisalii Duangjan \& Wołowski (Fig. 8), T. volvocinopsis Svirenko (Fig. 9)] were partly overgrown with Colacium minimum cells.

BY1
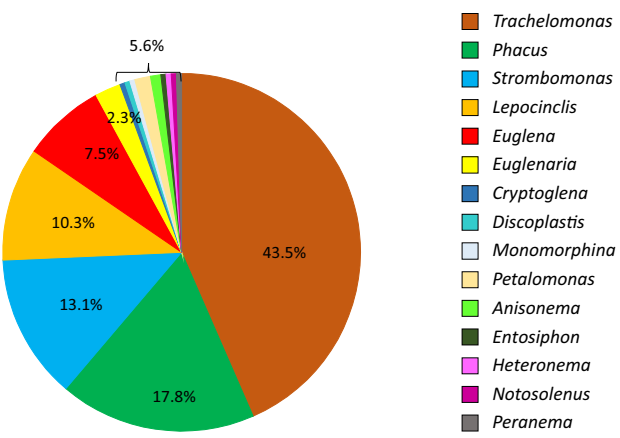

Fig. 4. Percentage of euglenoids occurring at BY site. 


\section{Colacium minimum Fott \& Komárek}

Figs 5-18

Cells slightly longitudinal $(3.8-4.5 \mu \mathrm{m}$ long, $3.2-3.4 \mu \mathrm{m}$ wide) to circular $(3.7-6.6 \mu \mathrm{m}$ in diameter), smooth, chloroplasts $2-4$, small, plateshaped, parietal without pyrenoids, pellicle smooth; stigma small, red, located at reservoir (Figs 15-18). Freely swimming cell with flagella up to twice longer than cell length. Cells attach to substrate by anterior end, secreting a thin, flat, dark brown stalk (Figs 12 \& 15). During cell division, can form aggregate of cells covering surface of loricated euglenoids (Figs $7 \& 8$ ) or can occur singly.

Distribution. Colacium minimum has been reported so far only from four localities in South Bohemia, Czech Republic (Fott \& Komárek
1960; Kaštovský et al. 2009; Jurán̆ 2010). The species is reported here for the first time from Thailand. These records are the first from the Asian continent.

In SEM we saw that our specimens differ slightly in shape from those described by Fott and Komárek (1960) (Table 2), probably as a result of drying.

Circular forms of epiphytes similar to Colacium minimum (Table 2) were observed on the surface of Trachelomonas by Wille (1901), who documented them with drawings marking their place of attachment at the posterior part of the lorica, and classified them as Sykidion chlorococcal green algae. Later that taxon (Sykidion droebakens) was reported by Hindák (2005) but attached to the surface of Crustacea. Bourrelly and Georges (1953) found specimens attached to the surface
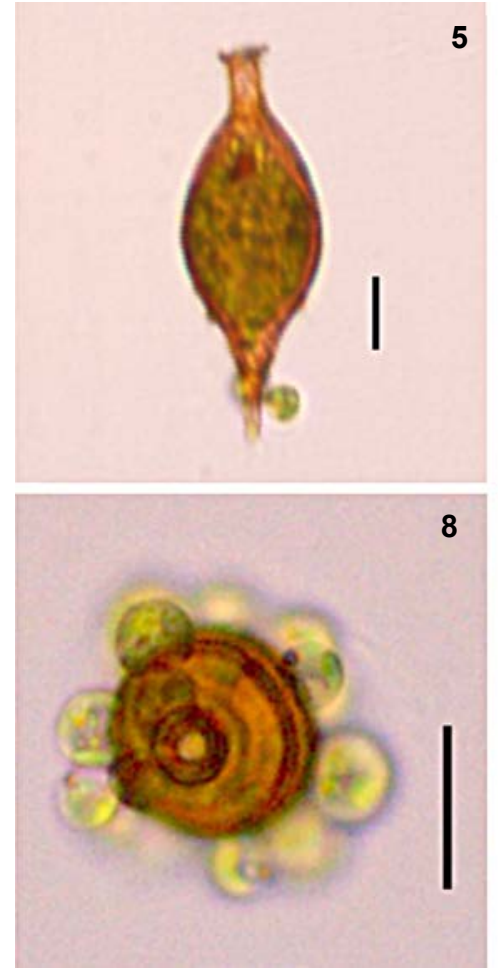
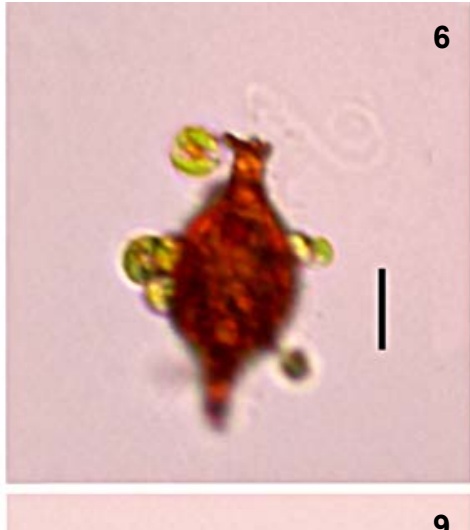

9

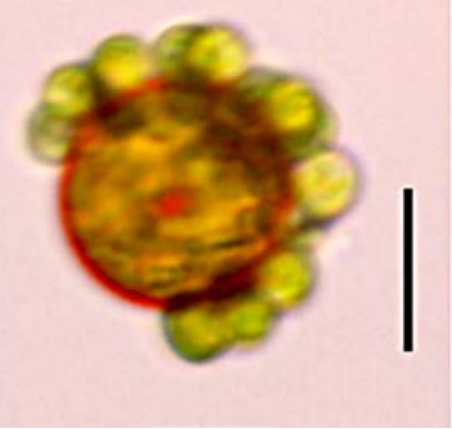

7
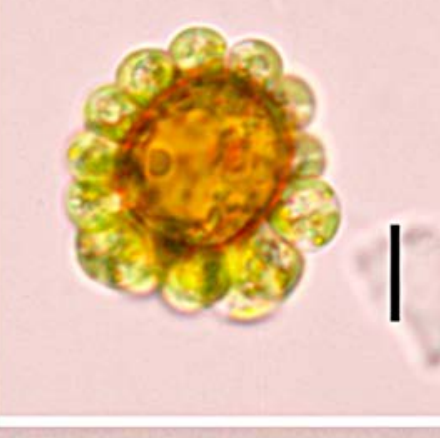

10

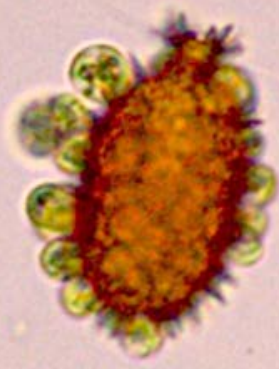

Figs 5-10. Colacium minimum Fott \& Komárek attached to two genera of euglenoids in natural conditions, LM: 5 \& 6 - Strombomonas Deflandre, $5-$ S. australica (Playfair) Deflandre, 6 - S. fluviatilis (Lemmermann) Deflandre, 7-10 - Trachelomonas Ehrenb.: 7 - T. akressiensis Da \& Couté, 8 - T. peerapornpisalii Duangjan \& Wołowski, $9-$ T. volvocinopsis Svirenko, $10-$ T. mirabilis var. helvetica Huber-Pestalozzi. Scale bar $=10 \mu \mathrm{m}$. 

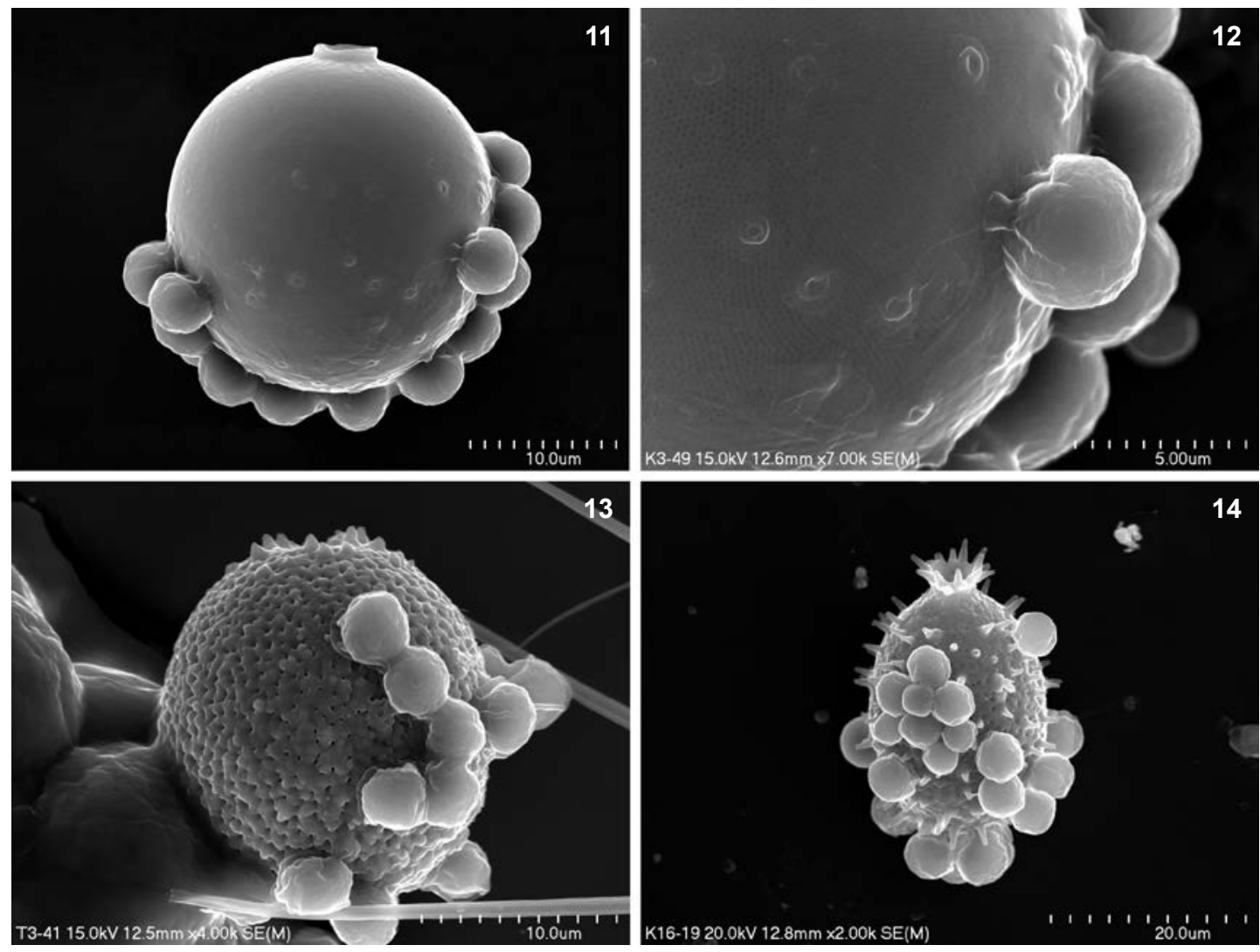

Figs 11-14. Colacium minimum Fott \& Komárek attached to surface of Trachelomonas Ehrenb., SEM: 11 - Trachelomonas cervicula var. heterocollis Svirenko, 12 - Colacium minimum Fott \& Komárek with well visible flat stalk, 13 - Trachelomonas intermedia f. papillifera Popova, 14 - T. mirabilis var. helvetica Huber-Pestalozzi. Scale bar $=10 \mu \mathrm{m}$.

of Trachelomonas and described them as Characiopsis epiphytica. In 1957, Skvortzov described Colacium trachelomonoides and mentioned that he observed only 2 lateral chloroplasts without pyrenoids (Skvortzov 1957). Three years later, Fott and Komárek (1960) reported the occurrence of Colacium minimum on the surface of Strombomonas and Trachelomonas loricae and planktonic diatoms. They pointed out its morphological similarity to Characiopsis epiphytica, confirmed also by our observations.

Similarly to other euglenoids, all species of Colacium are able to transform from characteristic unicellular motile stages into non-motile cells during encystation, changing their original shape to ovoid, oval, and up to spherical (Buetow 1968; Hindák et al. 2000). Taxa of Colacium always form a reproductive cyst. For this process they need a stable substrate ensuring adequate conditions in that period, and they temporarily become epibionts. Before the stationary phases of development, the cells of $C$. minimum probably have an increased demand for iron and manganese compounds, which are components of loricated euglenoids (Dunlap \& Walne 1985).

Our study of numerous specimens confirmed that the rough surfaces of algae provide a good base for epiphytes to develop. Colacium minimum did not attach to the pellicle of other euglenoids, which are very smooth and thus have poor adhesion. Our finding of the species on eight taxa of loricated euglenoids in Asia adds to the data on this still poorly recognized phenomenon of colonization of euglenoids by epiphytic algae. 

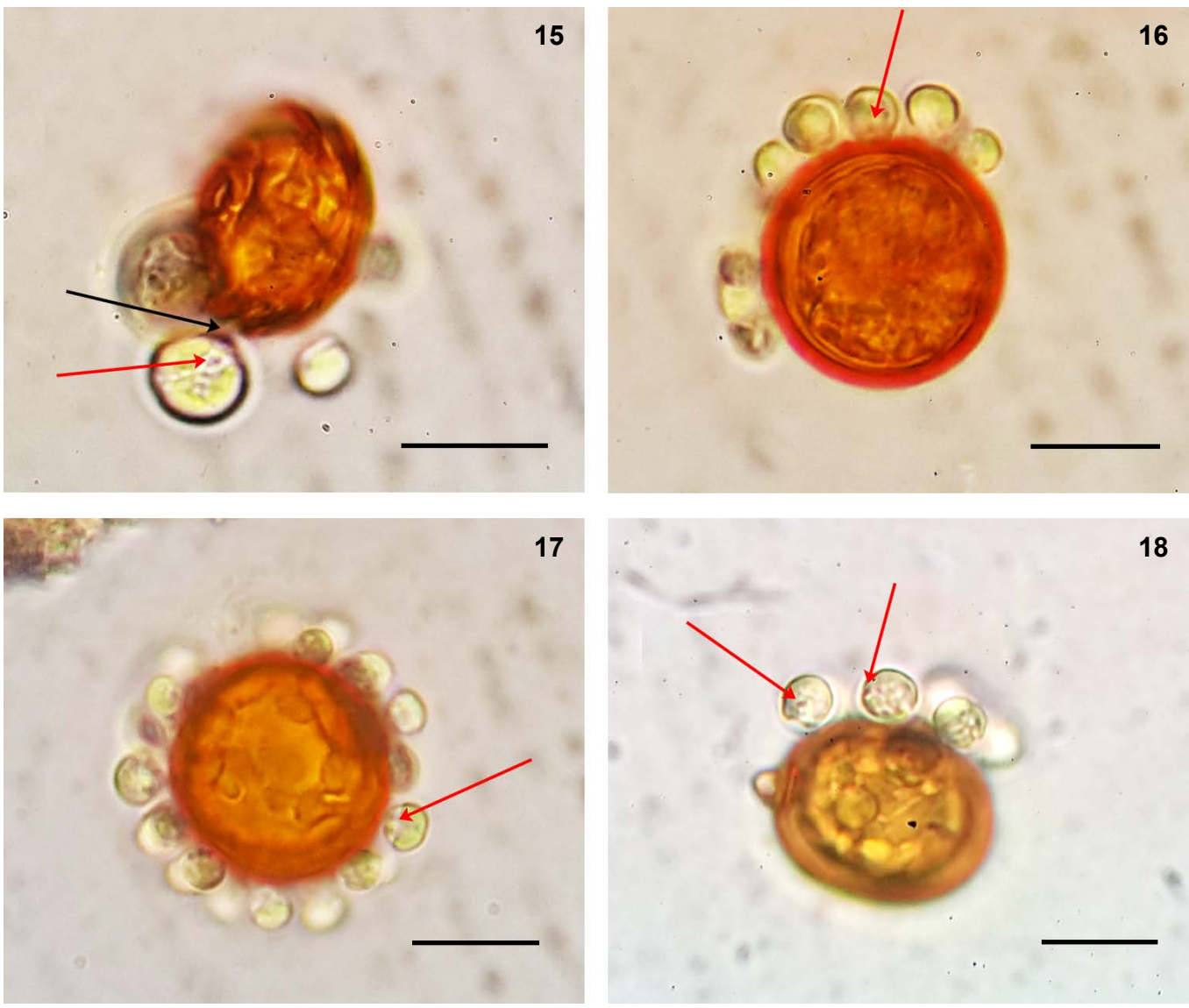

Figs 15-18. Cells of Colacium minimum Fott \& Komárek in various positions, with well-visible stigma (red arrows) and stalk (black arrow) LM. Scale bar $=10 \mu \mathrm{m}$.

Acknowledgements. We are grateful to Professor Pertti Eloranta (Helsinki) and the anonymous reviewer for helpful remarks and suggestions on the manuscript. This study was supported by the Royal Golden Jubilee Ph.D. Program of Thailand and by statutory funds of the W. Szafer Institute of Botany, Polish Academy of Sciences.

\section{REFERENCES}

Bourrelly P. \& Georges G. 1953. Quelques Algues ou nouvelles d'un Étang de Rambouillet (Ferme Nationale). Österr. Bot. Z. 100: 500-504.

BuEtow D. E. 1968. Morphology and ultrastructure of Euglena. In: D. E. Buetow (ed.), The biology of Euglena. 1: 110 181. Academic Press, New York and London.

Chudyba H. 1965. Cladophora glomerata and accompanying algae in the Skawa River. Acta Hydrobiol. 7(Suppl. 1): 93-126.

DuangJan K. \& Wolowski K. 2013. New taxa of loricate euglenoids Strombomonas and Trachelomonas from Thailand. Polish Bot. J. 58: 337-345.

Duanguan K., Wolowski K. \& Peerapornpisal Y. 2012. A taxonomic and ultrastructural study of Trachelomonas spp. (Euglenophyta) from agricultural area pond, Lamphun province. J. Microscopy Society of Thailand 5(1-2): 23-27.

DunlaP J. R. \& WALNE P. L. 1985. Fine structure and biomineralization of the mucilage envelopes of Trachelomonas Lefevrei (Euglenophyceae). J. Protozool. 32: 437-441.

Fotт B. \& KomáreK J. 1960. Das Phytoplankton der Teiche im Teschner Schlesien. Preslia 32: 113-141.

Greenberg A. E., Clesceri L. S. \& Eaton A. D. 2005. Standard methods for examination of water and waste water. $20^{\text {th }}$ ed. American Public Health Association (APHA), Washington DC. 
HINDÁK F. 2005. Zelené kokálne riasy (Chlorococcales, Chlorophyceae). Slovdenská Vodohospodárska Spoločnost', Bratislava.

Hindák F., Wolowski K. \& Hindákowa A. 2000. Cysts and their formation in some neustonic Euglena species. Ann. Limnol. 36(2): 83-93.

Huber-Pestalozzi G. 1955. Das Phytoplankton des Süßwassers. In: A. Thienemann, Die Binnengewässer. 16(4): 1-606. Euglenophyceen. E. Schweizerbart'sche Verlagsbuchhandlung, Stuttgart.

JURÁŇ J. 2010. Euglenophyta České republiky se zřetelem na oblast jižních Čech a Šumavy. Bachelor thesis, University of South Bohemia. Faculty of Natural Science. České Budějovice.

KaŠTovskÝ J., Hauer T. \& LuKavskÝ J. 2009. Sinice a řasy. [October 2015]. http://www.sinicearasy.cz.

KAWECKA B. 1980. Sessile algae in European mountain streams. I. The ecological characteristics of communities. Acta Hydrobiol. 22: 361-420.

SiLva P. C. 2007. Index Nominum Algarum, University Herbarium, University of California, Berkeley. [August 2015]. http://ucjeps.berkeley.edu/CPD.

Rosowski J. R. \& Kugrens P. 1973. Observation on the Euglenoid Colacium with special reference to the formation and morphology of attachment material. J. Phycol. 9(4): 370-383.

Rosowski J. R. \& WiLley R. L. 1977. Development of mucilaginous surfaces in euglenoids. I. Stalk morphology of Colacium mucronatum. J. Phycol. 13(1): 16-21.
Skvortzov B. V. 1957. New and rare flagellate from Manchuria, Eastern Asia. Phillipine Journal of Science 86: 139-202.

Starmach K. 1983. Euglenophyta - Eugleniny. Flora Słodkowodna Polski. 3. Państwowe Wydawnictwo Naukowe, Warszawa.

Whitton B. A. 1970. Biology of Cladophora in freshwater. Water Res. 4: 457-476.

Wille N. 1901. Studien über Chlorophyceen. I-VII. Skr. Vidensk.-Selsk.Christiana, Math.-Naturvidensk. Kl. 6(1900): 1-46.

Willey R. L. \& Giancarlo J. G. 1986. Cell attachment mechanisms in the flagellate, Colacium (Euglenophyceae). In: L. V. Evans \& K. D. Hoagland (eds), Algal biofouling, pp. 65-78. Elsevier, New York.

WOŁOWSKI K. 1998. Taxonomic and environmental study on euglenophytes of the Kraków-Częstochowa upland (southern Poland). Fragm. Florist. Geobot. Suppl. 6: 1-192.

WoŁowski K. 2011. Phylum Euglenophyta. In: D. M. John, B. A. Whitton \& A. Brook (eds), The freshwater Algal Flora of the British Isles. 2 ed. Cambridge University Press, Cambridge.

Wolowski K. \& Hindák F. 2005. Atlas of euglenophytes. VEDA, Bratislava. 